\title{
Effect of nutritional vitamin D preparations on parathyroid hormone in patients with chronic kidney disease
}

\author{
Chrysoula Pipili • Chrysostomos Dimitriadis • \\ Nigar Sekercioglu • Joanne M. Bargman • \\ Dimitrios D. Oreopoulos
}

Received: 28 April 2011/ Accepted: 11 August 2011/Published online: 26 August 2011

(C) Springer Science+Business Media, B.V. 2011

\section{Introduction}

Vitamin D deficiency is common and may be a risk factor for nearly all major diseases, including cancer, infections, autoimmune and cardiovascular disease [1]. Vitamin D (VitD) stores decline with age, during winter, after menopause and in chronic kidney disease (CKD) [2]. VitD supplementation is advocated for the treatment of musculoskeletal disorders, for prevention of fractures and secondary hyperparathyroidism [3].

\section{Vitamin D metabolism}

To appreciate the impact of VitD on parathyroid hormone (PTH), it may be useful to review VitD sources and metabolism. VitD synthesis involves the conversion of 7-dehydrocholesterol to $\mathrm{VitD}_{3}$ (cholecalciferol) by ultraviolet B rays from sunlight. Dietary intake of VitD is usually limited. Only a few foods contain $\mathrm{VitD}_{3}$, mostly fatty fish such as salmon and mackerel, fish oil, and to a lesser extent eggs. Enriched foods and supplements contain $\mathrm{VitD}_{3}$ or $\mathrm{VitD}_{2}$ (ergocalciferol), a steroid available from plant sources. Both $\mathrm{VitD}_{2}$ and $\mathrm{VitD}_{3}$ are stored in adipose tissue or converted to 25

C. Pipili $(\varangle) \cdot$ C. Dimitriadis · N. Sekercioglu •

J. M. Bargman · D. D. Oreopoulos

University of Toronto, University Health Network,

East Wing, 8th Floor Room 408, 399 Bathurst St.,

Toronto, ON M5T 2S8, Canada

e-mail: chrysapi2001@gmail.com hydroxy vitamin $\mathrm{D}[25(\mathrm{OH}) \mathrm{D}]$ or calcidiol in the liver. $25(\mathrm{OH}) \mathrm{D}$ circulates bound to VitD-binding protein and is metabolized to $1,25(\mathrm{OH})_{2} \mathrm{D}$ (calcitriol), the most active form of VitD, through the action of 1a-hydroxylase. Although 1a hydroxylase is expressed predominantly in the kidney, it has also been detected in a variety of extrarenal tissues such as the vasculature, gastrointestinal tract, skin, mammary epithelial cells, osteoblasts and osteoclasts [4]. Calcitriol produced locally is considered to have autocrine and paracrine actions on cellular proliferation and differentiation, apoptosis, insulin and renin secretion, interleukin and bactericidal proteins [5]. Calcitriol synthesis may also be modulated by vitamin $\mathrm{D}$ receptors on the cell surface; downregulation of these receptors may play an important role in regulating vitamin D activation [6]. Increased levels of PTH and hypophosphatemia stimulate expression of 1 a-hydroxylase, while Fibroblast Growth Factor 23 (FGF23) -secreted by osteocytes in the bone matrix-inhibits the expression of the enzyme and thus calcitriol synthesis [7].

Persistent nutritional Vitamin D shortage leads to intestinal calcium malabsorption, resulting in hypocalcemia and PTH secretion, causing secondary hyperparathyroidism. Its deficiency has been described as the main pathogenetic mechanism for rickets in children, osteomalacia in adults and osteoporosis in the elderly [8]. Calcidiol [25(OH)D] also has activity in bone and intestine, but is only one percent as potent as calcitriol. $25(\mathrm{OH}) \mathrm{D}$ deficiency has been associated with increased falls, cancer risk, hypertension, fibromyalgia-like 
symptoms, rheumatologic disease, diabetes, depression and fractures [9]. In addition, low levels of $25(\mathrm{OH}) \mathrm{D}$ have been recently linked to the presence of metabolic syndrome and cardiovascular mortality [10].

\section{Vitamin D and PTH in the general population}

In the general population, most data suggest that oral administration of inactive VitD (ergocalciferol or cholecalciferol) leads to an increase in $25(\mathrm{OH}) \mathrm{D}$ and to a linear reduction in PTH [11]. Initially, it had been suggested that the reduction in PTH with VitD supplementation reaches a plateau level, after which PTH starts to increase. Several workers have tried to identify the $25(\mathrm{OH}) \mathrm{D}$ cutoff point for maximal suppression of PTH [11, 12]; however, uncertainty in the available data about the contribution of sunshine, diet and age makes it difficult to determine the VitD requirements to achieve this plateau. Therefore, the exact serum $25(\mathrm{OH}) \mathrm{D}$ cutoff threshold to define optimal VitD status remains controversial. Some consider VitD insufficiency present at levels of serum $25(\mathrm{OH}) \mathrm{D}$ below $20 \mathrm{ng} / \mathrm{mL}(50 \mathrm{nmol} / \mathrm{L})$ or $30 \mathrm{ng} / \mathrm{mL}$ (75 nmol/L). Individuals with serum $25(\mathrm{OH}) \mathrm{D}$ values less than $20 \mathrm{ng} / \mathrm{mL}(50 \mathrm{nmol} / \mathrm{L})$ are classified as VitD deficient [11, 13]. These ranges were accepted because in most studies when serum 25(OH)D levels fall below $30 \mathrm{ng} / \mathrm{mL}$ ( $75 \mathrm{nmol} / \mathrm{L})$, PTH levels rise $[3,14,15]$ and calcium absorption is suboptimal [16].

\section{Chronic kidney disease}

Correlations of hypovitaminosis D with increased mortality, glucose intolerance and bone fractures have been observed in patients with end stage renal disease receiving dialysis [17-19]. Generally, patients with CKD are predisposed to low calcitriol $\left(1,25(\mathrm{OH})_{2} \mathrm{D}\right)$ levels due to the progressive lack of kidney mass to perform 1a-hydroxylation, increasing age, reduced sun exposure and immobilization [20, 21]. Uremia impairs the response to ultraviolet B rays [22] and, in animal models, reduces calcidiol synthesis secondary to PTH -mediated reduction in liver CYP450 isoforms [23]. Moreover, uremic plasma contains factors that inhibit nuclear uptake of calcitriol receptor and 1a -hydroxylase activity [24, 25].
The best indicator of VitD insufficiency is the serum level of 25(OH)D [26]. Blood levels of $25(\mathrm{OH}) \mathrm{D}$ reflect the total VitD derived from diet, sunlight exposure and adipose store [7]. Studies have reported varying prevalence rates of VitD deficiency in predialysis and dialysis patients ranging between 70 and 98\% [23, 27] and 51 and 100\% [28, 29], respectively. Patients with severe proteinuria have the lowest 25(OH)D levels (probably because of losses of protein-bound 25(OH)D) [30], while patients on $\mathrm{PD}$ have significantly lower levels of $25(\mathrm{OH}) \mathrm{D}$ compared to those on $\mathrm{HD}$ (probably because of increased 25(OH)D losses in the peritoneal effluent) [31].

In general, in patients with $\mathrm{CKD}$, an inverse correlation between plasma 25(OH)D and PTH has been noted. Extensive published evidence [22, 23, 26, 27, 32-35] demonstrates a modest decrease in PTH levels after calcidiol supplementation that does not, however, correct the PTH levels to normal. VitD supplementation is not accompanied by an increased risk of hypercalcemia and hyperphosphatemia.

Data are conflicting in terms of PTH reduction after VitD repletion in various CKD stages. Initial studies [36-38] found that, as renal insufficiency progresses, vitamin $\mathrm{D}_{2}$ supplementation led to less reduction in serum PTH. Patients with CKD stage 3 benefited more from VitD supplements, than those with CKD stage 4 and those on maintenance hemodialysis (HD). Ergocalciferol administration had a favorable impact on PTH decline only if there was an increase in $25(\mathrm{OH}) \mathrm{D}$ levels. An increase in serum $25(\mathrm{OH}) \mathrm{D}$ level greater than $5 \mathrm{ng} / \mathrm{mL}(>12.5 \mathrm{nmol} / \mathrm{L})$ was associated with significant likelihood of a greater than 30\% decrease in intact PTH [32].

Contrary to the previous studies, a recent metaanalysis [27] found that the significant decline in PTH levels after VitD supplementation was more pronounced in dialysis patients and in transplant recipients compared to predialysis CKD patients. This meta-analysis included patients with all stages of CKD (predialysis, on HD, on peritoneal dialysis and after renal transplantation) enrolled in observational and randomized control studies from 1996 to 2009; outcomes were most obvious in the 17 observational studies included in the meta-analysis pool, whereas in the randomized control studies the results were not as prominent. In the observational studies, a mean increase of $24 \mathrm{ng} / \mathrm{mL}(60 \mathrm{nmol} / \mathrm{L})$ in VitD level was associated with a decrease in PTH of 
$41 \mathrm{pg} / \mathrm{mL}(4.34 \mathrm{pmol} / \mathrm{L})$ in predialysis CKD patients and $59 \mathrm{pg} / \mathrm{mL}(6.25 \mathrm{pmol} / \mathrm{L})$ among $\mathrm{HD}$ patients, respectively [27].

The complementary role of VitD preparations to standard of care (calcitriol or its analogs, cinacalcet and surgical parathyroidectomy) for secondary hyperparathyroidism in CKD has also been assessed. Patients on maintenance HD treated simultaneously with VitD supplements in addition to the usual standard of care for secondary hyperparathyroidism have been followed up for 6 years. In these patients, the degree of hyperparathyroidism and the need for calcitriol analogs, cinacalcet and surgical parathyroidectomy were decreased drastically [32].

Given the fact that excess of calcitriol accelerates uremic vascular calcification [39], the use of lower doses of calcitriol in combination with calcidiol or the use of more selective VDR activators may result in cardiovascular disease prevention. To the same direction may lead the emergence of proteins inhibiting vascular mineralization. Osteoprotegerin -by binding several proinflammatory and promineralizing agents in circulation- and Fetuin-A -by antagonizing the action of growth factor and by promoting the phagocytosis of apoptotic bodies- are worth mentioning calcification inhibitors. Matrix GLa protein, despite the strong background from genetics, did not demonstrate association with calcium phosphate balance or vascular calcification in CKD patients [40].

\section{Mechanism of PTH decrease with VitD} supplementations

The mechanism through which VitD administration decreases elevated PTH levels remains to be clarified. PTH reduction could be attributed to either increased downstream calcitriol production, due to renal or extrarenal 1a hydroxylation of $25(\mathrm{OH}) \mathrm{D}$, or/and to $25(\mathrm{OH}) \mathrm{D}$ actions independent of calcitriol generation $[33,34]$. Indeed, in vitro models [41] have shown that $25(\mathrm{OH}) \mathrm{D}$ can directly activate the VitD receptor in the parathyroid gland without calcitriol involvement. Similarly, potential 25(OH)D actions could be seen indirectly among HD population. As noted previously, these patients benefited most from nutritional VitD preparations, although they might have a further calcitriol decline enhanced by the elevated FGF 23 $[42,43]$; it takes at least 6 months of VitD supplementation to increase calcitriol levels in HD patients [44].
The positive correlation between serum $25(\mathrm{OH}) \mathrm{D}$ and $1,25(\mathrm{OH})_{2} \mathrm{D}$ levels was documented only in VitD insufficient CKD patients, but not in persons with normal renal function [30, 45]. 25(OH)D probably exhibits biologic actions affecting patients with CKD differently compared with normal individuals [46].

The Kidney Disease Improving Global Outcome Initiative (KDIGO) recommends monitoring the serum $25(\mathrm{OH}) \mathrm{D}$ in stage 3-4 CKD and the treatment of patients with elevated PTH and 25(OH)D level less than $30 \mathrm{ng} / \mathrm{mL}(75 \mathrm{nmol} / \mathrm{L})$ with oral VitD preparation $[47,48]$. Cholecalciferol therapy leads to upregulation of VitD response genes in monocytes of patients on maintenance $\mathrm{HD}$, indicating that oral VitD preparations have a biologic effect on circulating monocytes and associated inflammatory markers in HD patients $[33,36,49]$.

Unresolved controversies surrounding 25(OH)D administration in patients with CKD

We do not have well-designed randomized clinical trials or large epidemiologic studies that examine fully the responses of PTH to oral VitD administration in CKD patients. Furthermore, no optimal 25(OH)D level has been established [7]. The available studies applied various VitD repletion approaches (relating to dose, duration, and route of administration and monitoring of $25(\mathrm{OH}) \mathrm{D})$ and targeted dissimilar ranges of serum 25(OH)D levels. The two forms of nutritional VitD $\left(D_{2}, D_{3}\right)$ were regarded as equal and interchangeable [50], while recent literature suggests that $\mathrm{VitD}_{3}$ (cholecalciferol) is more potent than $\mathrm{VitD}_{2}$ (ergocalciferol) at lowering PTH levels [51-53]. Considering the advantages of various VitD analogs, such as low cost, minor risks for hypercalcemia and hyperphosphatemia, and survival benefit on HD population [54], it will be of interest to explore their usefulness, especially to determine whether concurrent use of $25(\mathrm{OH}) \mathrm{D}$ with $1,25(\mathrm{OH})_{2} \mathrm{D}$ or calcimimetics will provide better outcomes.

\section{Conclusion}

VitD deficiency is common among CKD patients, and many authors have assessed the benefits of calcidiol repletion in those patients. We reviewed the potential effect of oral vitamin D preparations on secondary 
hyperparathyroidism in CKD patients. The correction of VitD status might be a novel pharmacological approach to further optimize existing therapies in CKD patients with secondary hyperparathyroidism.

\section{References}

1. Mertens PR, Müller R (2010) Vitamin D and cardiovascular risk. Int Urol Nephrol 42(1):165-171

2. Ginde AA, Liu MC, Camargo CA Jr (2009) Demographic differences and trends of vitamin D insufficiency in the US population, 1988-2004. Arch Intern Med 169(6):626-632

3. Holick MF (2007) Vitamin D deficiency. N Engl J Med 357(3):266-281

4. Hewison M, Burke F, Evans KN, Lammas DA, Sansom DM, Liu P, Modlin RL, Adams JS (2007) Extra-renal 25hydroxyvitamin D3-1alpha-hydroxylase in human health and disease. J Steroid Biochem Mol Biol 103(3-5):316

5. DeLuca HF (2004) Overview of general physiologic features and functions of vitamin D. Am J Clin Nutr 80(6 Suppl):1689S

6. Dusso AS, Thadhani R, Slatopolsky E (2004) Vitamin D receptor and analogs. Semin Nephrol 24(1):10-16

7. Rosen CJ (2011) Clinical practice. Vitamin D insufficiency. N Engl J Med 364(3):248-254

8. Lips P (2001) Vitamin D deficiency and secondary hyperparathyroidism in the elderly: consequences for bone loss and fractures and therapeutic implications. Endocr Rev 22(4):477-501

9. LaClair RE, Hellman RN, Karp SL, Kraus M, Ofner S, Li Q, Graves KL, Moe SM (2005) Prevalence of calcidiol deficiency in CKD: a cross-sectional study across latitudes in the United States. Am J Kidney Dis 45(6):1026-1033

10. Dobnig H, Pilz S, Scharnagl H, Renner W, Seelhorst U, Wellnitz B, Kinkeldei J, Boehm BO, Weihrauch G, Maerz W (2008) Independent association of low serum 25-hydroxyvitamin D and 1, 25-dihydroxyvitamin D levels with all-cause and cardiovascular mortality. Arch Intern Med 168(12):1340-1349

11. Björkman M, Sorva A, Tilvis R (2009) Responses of parathyroid hormone to vitamin $\mathrm{D}$ supplementation: a systematic review of clinical trials. Arch Gerontol Geriatr 48(2):160-166

12. Aloia JF, Talwar SA, Pollack S, Yeh J (2005) A randomized controlled trial of vitamin D3 supplementation in African American women. Arch Intern Med 165(14):16181623

13. Vieth R, Bischoff-Ferrari H, Boucher BJ, Dawson-Hughes B, Garland CF, Heaney RP, Holick MF, Hollis BW, Lamberg-Allardt C, McGrath JJ, Norman AW, Scragg R, Whiting SJ, Willett WC, Zittermann A (2007) The urgent need to recommend an intake of vitamin $\mathrm{D}$ that is effective. Am J Clin Nutr 85(3):649-650

14. Heaney RP (2005) The vitamin D requirement in health and disease. J Steroid Biochem Mol Biol 97(1-2):13-19

15. Steingrimsdottir L, Gunnarsson O, Indridason OS, Franzson L, Sigurdsson G (2005) Relationship between serum parathyroid hormone levels, vitamin D sufficiency, and calcium intake. JAMA 294(18):2336-2341

16. Chapuy MC, Preziosi P, Maamer M, Arnaud S, Galan P, Hercberg S, Meunier PJ (1997) Prevalence of vitamin D insufficiency in an adult normal population. Osteoporos Int 7(5):439-443

17. Bindal ME, Taskapan H (2010) Hypovitaminosis D and insulin resistance in peritoneal dialysis patients. Int Urol Nephrol PMID: 14748937

18. Ambrus C, Almasi C, Berta K, Deak G, Marton A, Molnar MZ, Nemeth Z, Horvath C, Lakatos P, Szathmari M, Mucsi I (2010) Vitamin D insufficiency and bone fractures in patients on maintenance hemodialysis. Int Urol Nephrol PMID: 20237846

19. Neves PL, Malho A, Cabrita A, Pinho A, Baptista A, Morgado E, Faísca M, Carrasqueira H, Silva AP (2010) Statins and vitamin D: a friendly association in pre-dialysis patients. Int Urol Nephrol 42(1):173-179

20. Dusso AS, Brown AJ, Slatopolsky E (2005) Vitamin D. Am J Physiol Renal Physiol 289(1):F8-F28

21. Mosekilde L (2005) Vitamin D and the elderly. Clin Endocrinol (Oxf) 62(3):265-281

22. Blair D, Byham-Gray L, Lewis E, McCaffrey S (2008) Prevalence of vitamin D [25(OH)D] deficiency and effects of supplementation with ergocalciferol (vitamin D2) in stage 5 chronic kidney disease patients. J Ren Nutr 18(4): 375-382. [Erratum in: J Ren Nutr. 2009 Mar;19(2):195]

23. Michaud J, Naud J, Ouimet D, Demers C, Petit JL, Leblond FA, Bonnardeaux A, Gascon-Barré M, Pichette V (2010) Reduced hepatic synthesis of calcidiol in uremia. J Am Soc Nephrol 21(9):1488-1497

24. Hsu CH, Patel S (1992) Uremic plasma contains factors inhibiting 1 alpha-hydroxylase activity. J Am Soc Nephrol 3(4):947-952

25. Patel SR, Ke HQ, Vanholder R, Hsu CH (1994) Inhibition of nuclear uptake of calcitriol receptor by uremic ultrafiltrate. Kidney Int 46(1):129-133

26. Cronin SC (2010) The dual vitamin D pathways: considerations for adequate supplementation. Nephrol Nurs J 37(1):19-26, 36 [quiz 27-8]

27. Kandula P, Dobre M, Schold JD, Schreiber MJ Jr, Mehrotra R, Navaneethan SD (2011) Vitamin D supplementation in chronic kidney disease: a systematic review and meta-analysis of observational studies and randomized controlled trials. Clin J Am Soc Nephrol 6(1):50-62

28. Gracia-Iguacel C, Gallar P, Qureshi AR, Ortega O, Mon C, Ortiz M, Villarreal I, Garcia-Lacalle C, Olieta A, Sánchez M, Herrero JC, Vigil A, Lindholm B, Carrero JJ (2010) Vitamin $D$ deficiency in dialysis patients: effect of dialysis modality and implications on outcome. J Ren Nutr 20(6):359-367

29. Bhan I, Burnett-Bowie SA, Ye J, Tonelli M, Thadhani R (2010) Clinical measures identify vitamin D deficiency in dialysis. Clin J Am Soc Nephrol 5(3):460-467

30. González EA, Sachdeva A, Oliver DA, Martin KJ (2004) Vitamin D insufficiency and deficiency in chronic kidney disease. A single center observational study. Am J Nephrol 24(5):503-510

31. Sahin G, Kirli I, Sirmagul B, Colak E, Yalcin AU (2009) Loss via peritoneal fluid as a factor for low 25(OH)D3 level in peritoneal dialysis patients. Int Urol Nephrol 41(4):989-996 
32. McAdam-Marx C, Yu J, Bouchard J, Aagren M, Brixner DI (2010) Comparison of daily insulin dose and other antidiabetic medications usage for type 2 diabetes patients treated with an analog basal insulin. Curr Med Res Opin 26(1):191-201

33. Matias PJ, Jorge C, Ferreira C, Borges M, Aires I, Amaral T, Gil C, Cortez J, Ferreira A (2010) Cholecalciferol supplementation in hemodialysis patients: effects on mineral metabolism, inflammation, and cardiac dimension parameters. Clin J Am Soc Nephrol 5(5):905-911

34. Kalantar-Zadeh K, Shah A, Duong U, Hechter RC, Dukkipati R, Kovesdy CP (2010) Kidney bone disease and mortality in CKD: revisiting the role of vitamin $\mathrm{D}$, calcimimetics, alkaline phosphatase, and minerals. Kidney Int Suppl 117:S10-S21

35. Zisman AL, Hristova M, Ho LT, Sprague SM (2007) Impact of ergocalciferol treatment of vitamin D deficiency on serum parathyroid hormone concentrations in chronic kidney disease. Am J Nephrol 27(1):36-43

36. Binkley N, Ramamurthy R, Krueger D (2010) Low vitamin D status: definition, prevalence, consequences, and correction. Endocrinol Metab Clin North Am 39(2):287-301

37. Trakarnvanich T, Chalapipat O, Disthabanchong S, Kurathong S, Praditpornsilpa K, Stitchantrakul W, Chailurkit LO (2010) Effect of high dose ergocalciferol in chronic kidney disease patients with 25-hydroxyvitamin D deficiency. J Med Assoc Thai 93(8):885-891

38. Jean G, Vanel T, Terrat JC, Chazot C (2010) Prevention of secondary hyperparathyroidism in hemodialysis patients: the key role of native vitamin D supplementation. Hemodial Int 14(4):486-491

39. Rodriguez M, Martinez-Moreno JM, Rodríguez-Ortiz ME, Muñoz-Castañeda JR, Almaden Y (2011) Vitamin D and vascular calcification in chronic kidney disease. Kidney Blood Press Res 34(4):261-268

40. Stompór T (2007) An overview of the pathophysiology of vascular calcification in chronic kidney disease. Perit Dial Int 27(Suppl 2):S215-S222

41. Makin G, Lohnes D, Byford V, Ray R, Jones G (1989) Target cell metabolism of 1, 25-dihydroxyvitamin D3 to calcitroic acid. Evidence for a pathway in kidney and bone involving 24-oxidation. Biochem J 262(1):173-180

42. Jones G (2007) Expanding role for vitamin D in chronic kidney disease: importance of blood 25-OH-D levels and extra-renal 1alpha-hydroxylase in the classical and nonclassical actions of 1alpha, 25-dihydroxyvitamin $\mathrm{D}(3)$. Semin Dial 20(4):316-324
43. Sato T (2007) Renal bioactivation of vitamin D and its key modulators. Clin Calcium 17:686-690

44. Jean G, Terrat JC, Vanel T, Hurot JM, Lorriaux C, Mayor B, Chazot C (2008) Evidence for persistent vitamin D 1-alpha-hydroxylation in hemodialysis patients: evolution of serum 1,25-dihydroxycholecalciferol after 6 months of 25-hydroxycholecalciferol treatment. Nephron Clin Pract 110(1):c58-c65

45. Moe SM, Drüeke T, Lameire N, Eknoyan G (2007) Chronic kidney disease-mineral-bone disorder: a new paradigm. Adv Chronic Kidney Dis 14(1):3-12

46. Al-Badr W, Martin KJ (2008) Vitamin D and kidney disease. Clin J Am Soc Nephrol 3(5):1555-1560

47. Kidney Disease: Improving Global Outcomes (KDIGO) CKD-MBD Work Group (2009) KDIGO clinical practice guideline for the diagnosis, evaluation, prevention, and treatment of Chronic Kidney Disease-Mineral and Bone Disorder (CKD-MBD). Kidney Int Suppl (113):S1-S130

48. NKF/KDOQI clinical practice guidelines for bone metabolism and disease in chronic kidney disease. Availiable at: http://www.kidney.org/professionals/KDOQI/guidelines_ bone/index.htm

49. Stubbs JR, Idiculla A, Slusser J, Menard R, Quarles LD (2010) Cholecalciferol supplementation alters calcitriolresponsive monocyte proteins and decreases inflammatory cytokines in ESRD. J Am Soc Nephrol 21(2):353-361

50. Holick MF, Biancuzzo RM, Chen TC, Klein EK, Young A, Bibuld D, Reitz R, Salameh W, Ameri A, Tannenbaum AD (2008) Vitamin D2 is as effective as vitamin D3 in maintaining circulating concentrations of 25-hydroxyvitamin D. J Clin Endocrinol Metab 93(3):677

51. Armas LA, Hollis BW, Heaney RP (2004) Vitamin D2 is much less effective than vitamin D3 in humans. J Clin Endocrinol Metab 89(11):5387-5391

52. Binkley N, Krueger D, Gemar D, Drezner MK (2008) Correlation among 25-hydroxy-vitamin D assays. J Clin Endocrinol Metab 93(5):1804-1808 Epub 2008 Mar

53. Trang HM, Cole DE, Rubin LA, Pierratos A, Siu S, Vieth R (1998) Evidence that vitamin D3 increases serum 25-hydroxyvitamin D more efficiently than does vitamin D2. Am J Clin Nutr 68(4):854-858

54. Teng M, Wolf M, Ofsthun MN, Lazarus JM, Hernán MA, Camargo CA Jr, Thadhani R (2005) Activated injectable vitamin D and hemodialysis survival: a historical cohort study. J Am Soc Nephrol 16(4):1115-1125 